\title{
Targets and procedures for altering ruminant meat and milk lipids
}

\author{
D. Demeyer ${ }^{1 *}$ and M. Doreau ${ }^{2}$ \\ ${ }^{1}$ Department of Animal Production and Department of Nutrition and Food Technology, \\ University of Gent, Proefhoevestraat 10, 9090 Melle, Belgium \\ ${ }^{2}$ Ruminant Undernutrition Laboratory, Institut National de la Recherche Agronomique, \\ Theix, 63122 Saint-Genès-Champanelle, France
}

Beef and dairy products suffer from a negative health image, related to the nature of their lipid fraction. Rumen lipid metabolism involves the presence of saturated lipids in ruminant tissues. Lipolysis, fatty acid biohydrogenation and formation of microbial fatty acids in the rumen and their effects on rumen outflow of fatty acids are discussed. Special emphasis is given to the formation of trans-fatty acids and the possibilities of decreasing biohydrogenation. Small differences in intestinal digestibilities of fatty acids are mentioned, followed by a discussion on transfer of absorbed fatty acids into milk and adipose tissue lipids. The preferential retention of polyunsaturated fatty acids as well as the balance between synthesis and incorporation of fatty acids in tissues is described. Dietary means for the modification of milk fat are listed, with special emphasis on the possibilities for enrichment in polyunsaturated fatty acids and the presence of conjugated linoleic acids. A description of the nature and development of fat depots in beef cattle is followed by a discussion of breed, conformation and feed effects on adipose tissue distribution and fatty acid composition. Special emphasis is given to the very lean Belgian Blue doublemuscled breed. The review ends with a consideration of the limits to the modification of ruminant fats, involving considerations of consumer acceptance as well as animal welfare and environmental effects.

\section{Résumé}

\begin{abstract}
Les produits laitiers et la viande bovine souffrent d'une image santé négative, liée à la nature de leur fraction lipidique. Le métabolisme ruminal des lipides est la cause de la présence de lipides saturés dans les tissus des ruminants. La lipolyse, la biohydrogénation des acides gras et la formation d'acides gras microbiens dans le rumen, ainsi que les effets sur le flux d'acides gras à la sortie du rumen sont discutés. Une attention particulière est portée à la formation d'acides gras trans et aux possibilités de limiter la biohydrogénation. De faibles différences de digestibilité entre acides gras sont mentionnées, suivies par une discussion sur le transfert des acides gras absorbés dans le lait et les tissus adipeux. La rétention préférentielle d'acides gras polyinsaturés et le bilan entre synthèse et incorporation d'acides gras sont décrits. Les moyens nutritionnels de modifier la matière grasse du lait sont répertoriés, en particulier en vue d'accroïtre la sécrétion d'acides gras polyinsaturés et d'acide linoléique conjugué. Une description de la nature et du développement des tissus adipeux chez le bovin à viande est accompagnée d'une discussion des effets de la race, de la conformation et de la ration sur la distribution et la composition en acides gras des tissus adipeux. Le cas de la race blanc bleu belge à forte muscularité et très maigre est spécialement analysé. En guise de conclusion, des considérations sur les limites à la modification des lipides des ruminants font appel aux notions d'acceptabilité par le consommateur, de bien-être animal et d'effets sur l'environnement.
\end{abstract}

Beef and dairy products: Ruminant fats: Polyunsaturated fatty acids:

Belgian Blue double-muscled cattle

\footnotetext{
Abbreviations: CLA, conjugated linoleic acid; FA, fatty acid; PUFA, polyunsaturated fatty acids.

*Corresponding author: Professor D. Demeyer, fax +32 9264 9099, email Daniel.Demeyer@mug.ac.uk
} 
For many years, consumers in industrialized countries have displayed an aversion to dietary fat (Claus, 1991) and, for health reasons, nutritional guidelines advocate a decrease in the consumption of (saturated) fat (Gormley et al. 1987). Nevertheless, total fat intake in western Europe continues to amount to about $40 \%$ of the dietary energy intake, equivalent to $130 \mathrm{~g} / \mathrm{d}$. Milk and milk products are the major sources of fat in the diets, accounting, on average, for about $30 \%$ of the total fat and $40 \%$ of the saturated fat intake in the UK (Mansbridge \& Blake, 1997), Belgium (Demeyer et al. 1995a) and Germany (Flachowski \& Jahreis, 1997). Beef is estimated to contribute only about $5 \%$ of the total fat intake, but is regarded as a rich source of saturated fat. Milk and milk products can be made more nutritionally desirable through dairy technology, and can be upgraded by the incorporation of polyunsaturated fatty acids (PUFA), through, for example, directed or random interesterification without elaidization (Huyghebaert et al. 1994). Such technology, coupled, for example, with fractional crystallization helps to overcome the seasonal variation in milk fat properties (Deffense, 1993), but involves additional costs. W De Greyt (personal communication) estimates that factory production costs for single-stage milk fat fractionation amount to between 15 and 20 US\$ and about $325 \mathrm{MJ}$ per t milk fat. Furthermore, existing technology has been aimed mainly at optimization of functional properties related to, for example, texture of products, although dairy products enriched in PUFA have been listed as 'functional foods' (Van Dokkum, 1995). It is clear that the farmer does not profit from the added value of such products, whereas processing induces an additional burden on fossil energy use. Thus, for both social and ecological reasons, an intervention by the farmer rather than by the food technologist to make beef and milk fat attractive for consumption as healthy food is perhaps indicated. Several (bio)technologies supply the means for such interventions, aimed at target processes involving both digestion and/or tissue metabolism (Mersmann, 1990). The use of feed additives and growth promoters is often involved, clashing with the increasing requirements of consumers and regulation for improved quality of animal production and products. The present paper, therefore, will mainly discuss nutritional ways to improve the health value of milk and beef fat composition, particularly by increasing PUFA, adjusting the $n-3: n-6$ PUFA value and controlling trans-fatty acids (FA) and conjugated linoleic acid (CLA) in meat and milk. The paper summarizes information from other recent reviews (Demeyer et al. 1995b; Doreau et al. 1997; Doreau \& Chilliard, 1997b; Wood \& Enser, 1997), but emphasizes data obtained in Belgium, a country characterized by very intensive animal production and the use of extremely lean double-muscled cattle.

\section{Rumen metabolism and digestibility of lipids}

\section{Lipolysis}

Triacylglycerols, phospholipids and galactosyl lipids in ingested forage and concentrate feeds are rapidly hydrolysed in the rumen by extracellular lipases produced by a small number of bacteria. Some activity could be associated with the protozoal fraction (Harfoot \& Hazlewood, 1997). No intermediate production of partial acylglycerols has been demonstrated, and free FA form the major lipid fraction in rumen and duodenal lipids, even when high amounts of fat are fed. Lipolytic activity has been shown to be inhibited by pH values below 6 (Van Nevel \& Demeyer, 1996c) and by antibiotics such as ionophores (Van Nevel \& Demeyer, $1996 a$ ). From results of incubation of rumen contents with free soyabean oil (Van Nevel \& Demeyer, 1996a,c), it can be calculated that on average 67 and $80 \%$ of the linoleic and linolenic acids respectively were released from triacylglycerols, whereas $92 \%$ of the released FA were recovered after incubation, suggesting some specificity of lipolysis. At increasing rates of oil infusion into the rumen, the free FA : triacylglycerol and mono-: diunsaturated octadecenoic acid values in rumen total lipids and free FA respectively suggest that lipolytic activity is not limiting the rate of FA biohydrogenation in the rumen (Immig et al. 1993).

\section{Biohydrogenation}

Free FA liberated by lipolysis are adsorbed onto particles, where they are both hydrogenated and/or incorporated into the lipid fraction of the solid-associated bacteria. According to Harfoot \& Hazlewood (1997), the balance between these two processes is one of the factors determining the extent of FA biohydrogenation in the rumen. A range of hydrogenating bacteria have been isolated and can be divided into groups A and B. Group A hydrogenate linoleic and $\alpha$-linolenic acids mainly to the trans-11-octadecenoic acid (trans-11-18:1) or vaccenic acid, with smaller amounts of other positional and stereo-isomers of the same acid. The initial step in the biohydrogenation of linoleic acid involves the isomerization of the cis-9, cis-12-isomer to the cis-9, trans-11-isomer, which is followed by a preferential reduction of the cis-9 double bond to form the trans-11-18:1. Group A bacteria appear to be incapable of hydrogenating $18: 1$ acids, in contrast to the members of group B which are capable of hydrogenating a wide range of both cis- and trans-isomers of $18: 1$ to stearic acid. The trans-18:1 isomers normally comprise about $70 \%$ of rumen 18:1 acids, and it was shown in a continuous culture of rumen micro-organisms, using specific i.r. detection techniques, that free FA may contain up to seven trans- and six cis-18:1 acids. The trans-11 isomer represented at least $80 \%$ of the total trans-18:1 acids (Fellner et al. 1995). Trans-18:1 and conjugated octadecadienoic acids or CLA constituted 13 and $0.5 \%$ of the total FA respectively, whereas the conjugated diene isomers were shown to contain $33 \%$ of the cis-9, trans-11 isomer (Fellner et al. 1997). Biohydrogenation only occurs with free FA, but the system is easily overloaded, especially in vitro, with inhibition of the process by the free acids and accumulation of trans-18:1 and CLA. Biohydrogenation of linoleic acid in a continuous culture of rumen micro-organisms was shown to be inhibited by ionophores, with accumulation of trans-18:1 and CLA (Fellner et al. 1997). However, CLA does not arise in linolenic acid biohydrogenation (Harfoot \& Hazlewood, 1997). Inhibition of biohydrogenation $(5 \%)$ by ionophores and low $\mathrm{pH}$ was also found by Van Nevel \& Demeyer $(1996 a, c)$, but was less pronounced than inhibition of 
lipolysis $(20 \%)$. The inhibition of lipolysis and/or biohydrogenation by low $\mathrm{pH}$ may explain the increased degree of unsaturation in rumen and duodenal lipids (Kobayashi et al. 1992) and/or in body fat in animals fed on concentrate diets or treated with monensin. As shown by Gerson et al. (1985), however, other factors in addition to $\mathrm{pH}$, probably related to changes in microbial populations, must be involved with concentrate diets. Biohydrogenation of polyunsaturated $\mathrm{C}_{20}$ and $\mathrm{C}_{22} \mathrm{FA}$ from fish oil has been shown in vivo by Doreau \& Chilliard (1997a) and in vitro by Van Nevel et al. (1999). The latter authors found a slower lipolytic release of $18: 1$ acids from fish oil than from soyabean oil, and a significantly lower $(P<0.05)$ but nevertheless significant extent of hydrogenation for eicosapentanoic $(20: 5 n-3)$ and docosahexanoic $(22: 6 n-3)$ acids compared with other PUFA.

\section{Formation of microbial fatty acids}

It is now clear that both bacteria and protozoa can synthesize and/or incorporate higher FA, the synthesis possibly including, under some conditions, linoleic acid (for review, see Demeyer, 1973; Demeyer \& Hoozee, 1984). Incorporation includes linoleic acid being deposited in polar lipids or free FA. When high levels of free FA are available incorporation exceeds synthesis, whereas the opposite obviously occurs in the absence of added lipids (Demeyer et al. 1978; Bauchart et al. 1990). For the animal, bacterial lipids are more important than protozoal lipids, as protozoa are largely retained in the rumen. The bacterial lipids are characterized by a high proportion of branched-chain and unevennumbered straight-C-chain FA, synthesized from propionate and/or amino acids.

The main lipid fractions are free FA and polar lipids, and the FA composition reflects incorporation of dietary FA, as well as biohydrogenation and bacterial synthesis (Table 1). Although considerable variability is apparent from the data reported, it is clear that a mixture of liquid- and particleassociated bacteria, when leaving the rumen, contains between 100 and $200 \mathrm{mg}$ lipid/g DM, its FA containing between 5 and $15 \mathrm{mg}$ trans-18: 1 isomers/100 mg total FA, as well as $2-20 \mathrm{mg}$ PUFA/100 mg total FA, the higher values being obtained with diets comprising PUFA-rich lipid supplements. This value is not to be ignored; per $\mathrm{kg}$ DM intake, a diet of maize silage contains about $400 \mathrm{~g}$ organic matter apparently digested in the rumen, equivalent to the production of about $120 \mathrm{~g}$ bacterial DM, representing about $12 \mathrm{~g}$ newly-synthesized lipid. Since, apart from hydrogenation, all dietary lipid $(58 \mathrm{~g} / \mathrm{kg} \mathrm{DM})$ leaves the rumen mainly unaltered, it can be estimated that duodenal lipids may contain up to $17 \mathrm{~g}$ bacterial lipids $/ 100 \mathrm{~g}$ on such diets. Similar estimates have been reported previously (Jenkins, 1994; Demeyer \& Van Nevel, 1995; Mansbridge \& Blake, 1997).

\section{Rumen outflow of fatty acids}

Compared with rumen digesta, duodenal (Kobayashi et al. 1992) and abomasal (CJ Van Nevel \& DI Demeyer, unpublished results) digesta are slightly enriched in PUFA, a finding possibly related to the sloughing off of enterocytes. The duodenal flow of FA is generally higher than FA intake for diets not supplemented with lipids, but often lower for fat-supplemented diets. This finding probably reflects absorption or catabolism by rumen epithelial cells, and is apparent from relationships established between duodenal flow and intake of FA (Wu et al. 1991; Doreau \& Chilliard, 1997b). The intercepts of such relationships indicate that between 6 and $10 \mathrm{~g}$ bacterial FA/kg DM intake are synthesized, a value comparable with $12 \mathrm{~g} / \mathrm{kg}$ DM intake derived previously. FA degradation by rumen microbes in vitro is often minimal (Demeyer \& Van Nevel, 1995), but has been clearly observed in continuous culture (Fellner et al. 1995). With concentrate diets, the extent of hydrogenation of $\mathrm{C}_{18}$ PUFA is high; higher for linolenic acid (50-80\%) than for linoleic (35-60\%) acid and is generally lower for high-concentrate diets than for lowconcentrate diets, as indicated in the literature (Doreau et al. 1997). This finding is in line with the suggested specificity of lipolysis, and is obviously related to variations in rumen $\mathrm{pH}$ and in microflora, as discussed previously.

\section{Biohydrogenation and trans-fatty acids}

A striking feature of duodenal lipid composition is its high content of trans-isomers, increasing with the completeness of rumen biohydrogenation of added unsaturated oils, this factor being also determined by the balance between biohydrogenation and outflow of oils (Table 2). Contents of stereo-isomers and positional isomers of 18:1 are reported, but it is clear that cis, trans-conjugated dienoic acids must also be present in duodenal contents. Indeed, Noble et al. (1974) have shown that sheep rumen micro-organisms

Table 1. Fatty acid (FA) composition ( $\mathrm{mg} / 100 \mathrm{mg}$ ) of rumen bacterial lipids

\begin{tabular}{|c|c|c|c|c|c|}
\hline Reference... & $\begin{array}{c}\text { Mansbridge \& Blake } \\
\quad(1997)\end{array}$ & $\begin{array}{c}\text { Weisbjerg et al. } \\
\text { (1992) }\end{array}$ & $\begin{array}{c}\text { O’Kelly \& Spiers } \\
\text { (1991) }\end{array}$ & $\begin{array}{c}\text { Hussein et al. } \\
\text { (1995) }\end{array}$ & $\begin{array}{c}\text { Bauchart et al. } \\
\text { (1990) }\end{array}$ \\
\hline $\begin{array}{l}\text { Crude fat or total FA } \\
\text { (mg/g DM) }\end{array}$ & $50-90$ & $66-81$ & 98-237 & $146-163$ & $60-214$ \\
\hline \multicolumn{6}{|l|}{ SFA } \\
\hline Branched-chain & $12 \cdot 0$ & $5 \cdot 3-11 \cdot 4$ & $11 \cdot 4-17 \cdot 6$ & - & $3 \cdot 0-14 \cdot 7$ \\
\hline Short-chain & $73 \cdot 0$ & $51 \cdot 8-54 \cdot 6$ & $61 \cdot 2-72 \cdot 2$ & $65 \cdot 2-67 \cdot 8$ & $39 \cdot 8-64 \cdot 7$ \\
\hline trans-Isomers & - & $4 \cdot 4-5 \cdot 1$ & $3 \cdot 2-18 \cdot 7^{*}$ & - & - \\
\hline MUFA & $4 \cdot 0$ & $8 \cdot 4-13 \cdot 2$ & - & $22 \cdot 8-25 \cdot 8$ & $12 \cdot 5-35 \cdot 2$ \\
\hline PUFA & $4 \cdot 0$ & $1 \cdot 3-0 \cdot 8$ & 3.9 & $5 \cdot 6-5 \cdot 5$ & $6 \cdot 3-19 \cdot 9$ \\
\hline
\end{tabular}

* Mainly comprising the neutral-lipid fraction. SFA, saturated FA; MUFA, monounsaturated FA; PUFA, polyunsaturated FA. 
Table 2. trans-Octadecenoic acid (trans-18:1) content of duodenal fatty acids (FA) in relation to oil feeding and biohydrogenation

\begin{tabular}{|c|c|c|c|}
\hline Reference & Dietary treatment & trans-18: $1(\mathrm{mg} / 100 \mathrm{mg}$ total FA) & Biohydrogenation (\%)* \\
\hline \multirow[t]{3}{*}{ Wu et al. (1991) } & Diet: Alone & $4 \cdot 2$ & $67 \cdot 3$ \\
\hline & + Ca salt palm oil $(30 \mathrm{~g} / \mathrm{kg})$ & $3 \cdot 3$ & $58 \cdot 3$ \\
\hline & + Ca salt palm oil $(60 \mathrm{~g} / \mathrm{kg})$ & $2 \cdot 5$ & $53 \cdot 0$ \\
\hline \multirow[t]{3}{*}{ Enjalbert et al. (1994) } & Diet:+ soyabean oil (SO; 57 g/kg) & $37 \cdot 0$ & $89 \cdot 5$ \\
\hline & + emulsified SO $(57 \mathrm{~g} / \mathrm{kg})$ & 34.9 & $90 \cdot 9$ \\
\hline & + Ca salts SO $(67 \mathrm{~g} / \mathrm{kg})$ & 11.5 & $64 \cdot 3$ \\
\hline \multirow[t]{3}{*}{ Kalscheur et al. (1997) } & Diet: Alone & 6.7 & $71 \cdot 1$ \\
\hline & + $18: 1$ sunflower oil $(37 \mathrm{~g} / \mathrm{kg})$ & $18 \cdot 5$ & $79 \cdot 5$ \\
\hline & $+18: 2$ sunflower oil $(37 \mathrm{~g} / \mathrm{kg})$ & $20 \cdot 1$ & $80 \cdot 1$ \\
\hline
\end{tabular}

* Calculated as $100-100\left(\mathrm{C}_{18}\right.$ unsaturated FA in duodenum/ $\mathrm{C}_{18}$ unsaturated FA in diet), according to Wu et al. (1991).

produce trans-11-18:1 together with cis-9, trans-11-18:2 in vitro, and that the concentrations of both compounds reflect a product-precursor relationship when incubated with oils but not when incubated with free PUFA. Surprisingly, the feeding of high-oleate sunflower oil significantly increased the trans-18:1 content in total duodenal FA, although trans-isomers are not considered intermediates in the hydrogenation of oleic acid (cis-9-18:1). The trans11-18: 1 isomer makes up at least $80 \%$ of the trans-18:1 isomers in accordance with the hydrogenation pathways established for rumen bacteria.

\section{Techniques for decreasing biohydrogenation}

A natural protection against hydrogenation is given by the coat of some oilseeds, but this protection is limited. Moreover, extruding oilseeds does not improve protection. Thus, for more than two decades, physical and chemical techniques for the protection of feedstuffs against hydrogenation have been evaluated. The first method to be developed was the coating of emulsified oils with formaldehyde-treated proteins. This technique is for the moment the most efficient method of increasing the amount of PUFA absorbed (Gulati et al. 1997). Another form of physical treatment leads to prilled fats (i.e. dry and coated fat grains protected against rumen hydrogenation; Grummer, 1988), but the process has not been adapted for use with fats rich in PUFA. Ca salts are generally considered as inert fats. Although they do not affect microbial metabolism in the rumen, they are hydrogenated even more when FA are unsaturated and rumen $\mathrm{pH}$ is low, both factors increasing Ca salt dissociation (Ferlay et al. 1992; Van Nevel \& Demeyer, 1996b). The most recent technique, which is at the experimental stage, is the use of fatty acyl amides, which partially resist hydrogenation. Butylsoyamide may increase the rumen bypass of linoleic acid (Jenkins et al. 1996).

\section{Digestibility}

FA reaching the duodenum are mainly adsorbed on feed particles, bacteria and perhaps desquamated cells. The absence of monoacylglycerols in the ruminant duodenum is compensated for by the presence of lysolecithins in bile and their production from bacterial phospholipids by phospholipases. Together with bile salts they desorb the FA and solubilize them in the micellar phase, allowing absorption in the jejunum. FA digestibility can only be measured reliably between the duodenum and ileum or faeces. A literature survey revealed values ranging between 55 and $92 \%$. Variability was not explained by the level of FA intake. Digestibility does not differ between $\mathrm{C}_{16}$ and $\mathrm{C}_{18}$ FA and appears to be lower for $\mathrm{C}_{20}$ and $\mathrm{C}_{22} \mathrm{FA}$. Mean digestibilities for $\mathrm{C}_{18} \mathrm{FA}$ are $77,85,83$ and $76 \%$ for zero, one, two and three double bonds respectively (Doreau \& Chilliard, $1997 b$ ). It should be appreciated that values for $18: 1$ include the different isomers, whereas the low amounts of $18: 3$ may result in low accuracy of the estimates.

\section{Absorption and incorporation into milk and adipose tissue lipids}

\section{Transport}

The epithelial cells are the site for esterification into triacylglycerols and phospholipids, which are transported into the lymph as chylomicrons and VLDL, and further into the blood where these lipoproteins are found together with LDL and HDL. LDL, VLDL and chylomicrons contain approximately $10-15,60$ and $85 \mathrm{mg}$ triacylglycerols/100 g respectively. Most preformed FA are delivered to the mammary gland by LDL and VLDL. Although HDL account for approximately $90 \%$ of blood lipids they consist largely of phospholipids, cholesterol and cholesteryl esters, containing the major proportion of PUFA (Mansbridge \& Blake, 1997). Lipoproteins transport FA mainly to the mammary gland in dairy cattle and mainly to adipose and muscle tissue in fattening animals.

\section{Uptake by adipose tissue and by the mammary gland}

Uptake of HDL-FA by the mammary gland is poor, which may explain the low PUFA content of milk fat. During passage into these tissues, triacylglycerols are largely or completely hydrolysed by a lipoprotein lipase (EC 3.1.1.34). There is little further modification of preformed FA within these tissues, except for mild to extensive desaturation of medium- and long-chain FA, particularly $18: 0$, by a $\Delta 9$-desaturase. The result is a lower 18:0/18:1 value in these tissues compared with duodenal digesta, a mechanism thought to ensure fluidity of tissue and milk. Adipocytes and 
mammary gland tissue incorporate chylomicron-derived FA into triacylglycerols, using glycerol formed from glucose. The specificity of FA distribution within the triacylglycerols is determined during the esterification of glycerol-3phosphate with two FA, followed by the incorporation of a third FA into the dephosphorylated 1,2-diacyl-3-phosphate. Short-chain FA in milk triacylglycerols are, for example, esterified specifically at the 3 position. The FA distribution in adipose triacylglycerols conforms to the general rules formulated by Brockerhoff (1966) for mammalian depot triacylglycerols, i.e. saturated FA predominantly in the position $s n-1$, shorter-chain and unsaturated FA largely in position $s n-2$ and $\mathrm{C}_{18}$ and longer-chain FA in position $s n-3$. The branched-chain FA are mainly found in position $s n-2$, whereas the trans-18:1 isomers are distributed in a different manner from the cis-isomers ( $s n-2$ position) and are mainly found in the $s n-3$ position (Christie, 1981). Phospholipids are formed through reactions between diacylglycerols and cytidine phosphate components, involving specificity of the acyltransferases involved.

\section{Synthesis de novo}

Biosynthesis of adipose and milk lipids uses diet-derived FA as well as FA synthesized de novo from acetate. The effect of the former is limited, however, as de novo synthesis and direct incorporation are regulated and balanced in relation to optimal fluidity of both adipocyte and milk lipids and membranes. Adipose tissue is the major site of FA synthesis in ruminants, except during lactation when the mammary gland becomes the predominant site. Synthesis of FA up to palmitic acid takes place in the cytoplasm from acetyl-CoA and $\beta$-hydroxybutyrate derived from mitochondrial oxidation. Mitochondria elongate palmitic acid to longer FA up to $\mathrm{C}_{22}$, whereas microsomes are capable of elongation as well as desaturation of $\mathrm{FA} \geq \mathrm{C}_{18}$. Ruminants, as all mammals, in contrast to plants, are incapable however of the introduction of double bonds at C-9, counted from the carboxyl group and the methyl end of the chain (Gurr \& James, 1980). In the mammary gland, de novo synthesis is limited to short- and medium-chain FA (up to 16:0) that can be esterified only into the $s n-2$ and $s n-3$ positions of the glycerol backbone, thus the rate of FA synthesis in the mammary gland is dependent on the simultaneous supply of exogenous FA. Fatty acyl-CoA esters inhibit acetyl-CoA carboxylase ( $E C$ 6.4.1.2) in adipose tissue and mammary gland, and it has been shown with dispersed epithelial cells of both bovine and goat mammary glands that FA synthesized from acetate $\left(\mathrm{C}_{4}-\mathrm{C}_{16}\right)$ were incorporated into triacylglycerols, depending on the type and amount of exogenous FA added; palmitic acid stimulated synthesis and incorporation, whereas stearic and linoleic acids were inhibitory (Hansen \& Knudsen, 1987).

\section{Turnover and the balance between synthesis and incorporation}

As with all living tissues, the amounts of adipocyte lipids are the net result of both synthesis and degradation. Milk lipids, however, are secreted and thus subject to little turnover, this difference explaining the higher energetic efficiency of milk $v$. body tissue production. Turnover time of adipose tissue lipids varies with the level of feeding, physical activity and lactation, and may be up to hundreds of days. FA are liberated from adipose tissue for transportation as albumin-bound non-esterified FA to tissues requiring them for oxidative energy. Complex regulation of lipolytic activity occurs by both short- and long-term mechanisms, the former involving the action of a hormone-sensitive lipase, activated by adrenaline and inhibited by insulin. In the mammary gland, de novo synthesis is responsible for practically all FA up to $\mathrm{C}_{10}$ (short-chain FA) and for about half the medium-chain FA $(12: 0-16: 0)$. The other half of the medium-chain FA and practically all long-chain FA (18:0 and longer) are derived from blood FA originating from the diet or from mobilization of body fat stores (Baer, 1996). About $30 \%$ of milk fat is derived from acetate and perhaps $5 \%$ from $\beta$-hydroxybutyrate (Fredeen, 1996).

\section{Preferential retention of polyunsaturated fatty acids}

Ruminants attempt to specifically retain the small amounts of PUFA that escape hydrogenation by preferentially incorporating them into plasma cholesteryl esters via the lecithin-cholesterol acyl transferase (EC 2.3.1.43) pathway. It is also clear that they selectively incorporate polyenoic acids into membrane phospholipids. However, the ruminant has probably developed other mechanisms for the preferential retention of PUFA. Vernon \& Flint (1988) suggested limited oxidation of linoleic acid in ruminants, based on the finding that malonyl-CoA is much more effective in inhibiting carnitine acyltransferase when linoleyl-CoA is the substrate than when palmityl-CoA is the substrate in sheep liver, whereas the converse occurs in rat liver. Nevertheless, because of extensive rumen biohydrogenation, it has been suggested that ruminants can be delicately balanced in respect of their essential FA status (Ashes et al. 1995).

\section{Dietary methods for modifying milk fat}

Milk fat consists predominantly of triacylglycerol (98 mg/100 mg) with phospholipids and sterols comprising less than 1 and $0.5 \mathrm{mg} / 100 \mathrm{mg}$ total lipid respectively. Over $500 \mathrm{FA}$ are found esterified in the triacylglycerols. Their composition reflects the nature of dietary lipids, as well as the effects of rumen FA metabolism and FA synthesis in intestinal, mammary and adipose tissue. Saturated FA reaching the mammary gland are further desaturated by mammary desaturase activity, resulting in a lower $18: 0 / 18: 1$ value in milk $v$. duodenal digesta, a mechanism used by the ruminant to preserve the fluidity of milk. The predominant FA in milk are the short- and medium-chain saturated FA (mainly 12:0,14:0 and 16:0), accounting for about $50 \mathrm{mg} / 100 \mathrm{mg}$ total FA, and the long-chain FA (mainly 18:0 and 18:1) accounting for about $45 \mathrm{mg} / 100$ $\mathrm{mg}$ total FA and including small amounts of PUFA (2-3 mg, $18: 2$ and $18: 3 / 100 \mathrm{mg}$ total FA). The remainder consists of branched-chain and uneven-numbered saturated FA derived from bacterial lipids, as well as a series of trans- and positional isomers of $18: 1$ and $18: 2$. As discussed earlier, the distribution of FA over the three glycerol-C is not 
random and triacylglycerols from $\mathrm{C}_{24}$ to $\mathrm{C}_{54}$ are present (Kennelly, 1996a; Mansbridge \& Blake, 1997).

Such FA composition does not suggest a 'healthy' food, in view of the demonstrated serum LDL-raising properties of both saturated short- and medium-chain FA (Nicolisi, 1997) and of trans-unsaturated FA (Ip \& Marshall, 1996). Furthermore, milk fat consumption cannot contribute to an improvement in the PUFA intake and the $n-3: n-6$ value in human nutrition, as recommended in a number of dietary guidelines (Truswell, 1995). The proposal of an 'ideal' nutritional fat by the Wisconsin Milk Marketing Board, enriched in monounsaturated FA $(\geq 82 \%)$ and low in saturated FA ( $\leq 8 \%$; cited, for example, by Baer, 1996), and the new economical conditions of dairy production, especially in the EU, have resulted in pressure for a limitation of the production of milk fat and optimization of its FA composition.

Indeed, a number of countries outside and inside the EU value protein higher than fat with respect to milk payments, in line with the significant worldwide decline in the demand for milk fat, both as a result of substitution of vegetable spreads for butter and a consumer preference for milk with a reduced fat content (Kennelly, 1996a; Murphy \& O’Mara, 1993). In contrast to milk fat content, milk fatty acid composition only shows nutritionally insignificant differences between cattle breeds (DePeters et al. 1995). Nutrition, and in particular fat supplementation, may alter milk fatty acid composition towards that advised in nutritional guidelines.

\section{Effect of dietary fat}

Fat supplements have been shown to influence more than the reduction in the supply of precursors for fatty acid synthesis in the mammary gland. The following effects have been documented:

(a) an inhibition of FA synthesis through inhibition of acetyl-CoA carboxylase in both mammary and adipose tissue (Vernon \& Flint, 1988);

(b) an inefficient incorporation of PUFA, and particularly of the fish oil $\mathrm{C}_{20}$ and $\mathrm{C}_{22} \mathrm{FA}$ and the trans-isomers derived from rumen biohydrogenation, into the 1-monoacylglycerols required as acceptors for the newly-synthesized FA (Hansen \& Knudsen, 1987);

(c) an inefficient incorporation of trans- $v$. cis-FA into small and large triacylglycerols, not mediated at the level of lipoprotein lipase activity (Gaynor et al. 1994);

(d) a specific reduction in insulin-dependent amino acid $v$. non-insulin-dependent glucose and FA uptake by the mammary gland, due to an induction of insulin resistance by FA, leading to a reduction in milk protein content (Palmquist \& Moser, 1981). This reduction is brought about to the same extent by both cis- and trans18: 1 isomers (Gaynor et al. 1996).

Table 3 shows data illustrating a $23 \%$ decrease in the short- and medium-chain FA content with a corresponding $30 \%$ increase in the long-chain FA content as the result of supplementation with oil seeds. The latter increase mainly involves oleic acid. These effects are intensified by heat

Table 3. Effect of dietary unsaturated fat addition on milk fat yield and fatty acid (FA) composition (mg/100 g FA)

\begin{tabular}{|c|c|c|c|c|c|c|c|c|}
\hline & \multicolumn{2}{|c|}{ Murphy et al. (1995)* } & \multicolumn{2}{|c|}{ Chouinard et al. (1997)† } & \multicolumn{2}{|c|}{ Butantu (1996)‡ } & \multicolumn{2}{|c|}{ Chilliard et al. (1999)§ } \\
\hline & $\mathrm{P}$ & FFS & GSB & RSB & $\mathrm{MS}+\mathrm{C}$ & TSB & $S+C$ & $\mathrm{FO}$ \\
\hline $4: 0$ & 2.5 & 2.5 & $3 \cdot 3$ & $3 \cdot 3$ & $3 \cdot 8$ & $3 \cdot 8$ & $4 \cdot 2$ & $3 \cdot 7$ \\
\hline $6: 0$ & 1.9 & $1 \cdot 6$ & 2.5 & 2.5 & $2 \cdot 3$ & $1 \cdot 7$ & $2 \cdot 7$ & $2 \cdot 3$ \\
\hline $8: 0$ & $1 \cdot 2$ & 0.9 & $1 \cdot 6$ & 1.4 & $1 \cdot 3$ & 0.8 & $1 \cdot 6$ & 1.4 \\
\hline $10: 0$ & $2 \cdot 6$ & $1 \cdot 8$ & $4 \cdot 1$ & $3 \cdot 8$ & $3 \cdot 6$ & $2 \cdot 2$ & 3.9 & $3 \cdot 7$ \\
\hline $12: 0$ & $3 \cdot 2$ & $2 \cdot 0$ & $3 \cdot 7$ & 3.5 & 3.8 & 2.5 & $4 \cdot 8$ & $4 \cdot 8$ \\
\hline $14: 0$ & $11 \cdot 1$ & $7 \cdot 4$ & $10 \cdot 3$ & $9 \cdot 8$ & $12 \cdot 3$ & $9 \cdot 7$ & $11 \cdot 8$ & $12 \cdot 0$ \\
\hline $14: 1$ & 1.9 & $1 \cdot 2$ & 0.8 & 0.7 & - & - & $1 \cdot 1$ & $1 \cdot 0$ \\
\hline $16: 0$ & $23 \cdot 8$ & $19 \cdot 7$ & $23 \cdot 8$ & $22 \cdot 0$ & $35 \cdot 6$ & $27 \cdot 9$ & 28.9 & $27 \cdot 0$ \\
\hline $16: 1$ & 2.5 & $2 \cdot 2$ & $1 \cdot 8$ & 1.9 & - & - & $2 \cdot 3$ & 2.5 \\
\hline SMCFA & $50 \cdot 7$ & $39 \cdot 3$ & 51.9 & $48 \cdot 9$ & $62 \cdot 7$ & $48 \cdot 6$ & $61 \cdot 3$ & $58 \cdot 4$ \\
\hline $18: 0$ & $11 \cdot 1$ & $14 \cdot 2$ & $15 \cdot 4$ & $15 \cdot 3$ & $10 \cdot 8$ & $12 \cdot 8$ & $7 \cdot 2$ & $2 \cdot 3$ \\
\hline $18: 1$, trans -11 & & & $2 \cdot 3$ & $3 \cdot 6$ & - & - & $1 \cdot 1$ & $12 \cdot 5$ \\
\hline $18: 1$, cis- 9 & 28.5 & $35 \cdot 1$ & $20 \cdot 6$ & 21.9 & $24 \cdot 8$ & $34 \cdot 8$ & $16 \cdot 5$ & 5.9 \\
\hline $18: 3$ & 0.6 & 0.9 & $1 \cdot 2$ & $1 \cdot 2$ & - & - & 0.3 & 0.2 \\
\hline $20: 0$ & - & - & 0.4 & 0.4 & - & - & - & - \\
\hline $20: 5$ & - & - & - & - & - & - & 0 & 0.3 \\
\hline $22: 6$ & - & - & - & - & - & - & 0 & 0.4 \\
\hline LCFA & $42 \cdot 0$ & $55 \cdot 0$ & $45 \cdot 2$ & $48 \cdot 2$ & $37 \cdot 3$ & $51 \cdot 4$ & $27 \cdot 1$ & $23 \cdot 3$ \\
\hline Milk fat yield: $\mathrm{g} / \mathrm{d}$ & 539 & 558 & 1160 & 1140 & 887 & 977 & 783 & 567 \\
\hline $\mathrm{g} / \mathrm{kg}$ & $37 \cdot 5$ & $38 \cdot 1$ & $36 \cdot 5$ & $34 \cdot 2$ & $42 \cdot 0$ & $40 \cdot 4$ & 35.4 & $25 \cdot 1$ \\
\hline
\end{tabular}

SMFCA, short- and medium-chain FA (up to 16:0); LCFA, long-chain FA (from C $_{18}$ on); P, pasture; FFS, toasted full-fat soyabeans; GSB, RSB, TSB, ground, roasted and toasted soyabeans respectively; $M S+C$, maize silage and concentrate-based diet; $S+C$, silage and concentrate-based diet; FO, fish oil.

* Cows on P were fed on $3.2 \mathrm{~kg} \mathrm{FFS} / \mathrm{d}$.

† Holstein cows were fed on a mixed ration of silage and maize with GSB or RSB at $175 \mathrm{~g} / \mathrm{kg}$ DM in the total ration.

¥ Cows were fed on MS+C with or without TSB $(65 \mathrm{~g} / \mathrm{kg} \mathrm{DM}$ in the total ration).

$\S$ Also, Y Chilliard, JM Chardigny, J Chabrot, A Ollier, J-L Sebedio \& M Doreau (unpublished results). Holstein cows were fed on S+C with or without FO (300 ml). 
treatment of the soyabeans (Chouinard et al. 1997). However, experiments in vitro indicated inhibition of biohydrogenation by roasting soyabeans (Reddy et al. 1994). In contrast with soyabean oil, fish oil supply modifies the proportion of short- and medium-chain FA to a small extent, suggesting that inhibition of FA incorporation and inhibition of de novo synthesis are both associated with the decrease in fat content.

\section{Enrichment in linoleic acid and n-3 polyunsaturated fatty acids}

Until now, the only way to increase the linoleic acid content in milk has been to use oils protected by protein coating (Kennelly, 1996b). Unprotected oils or seeds and Ca salts of PUFA do not give a linoleic acid content in milk higher than $5 \mathrm{mg} / 100 \mathrm{mg}$ total FA (Doreau et al. 1997). The positive influence of $n-3$ PUFA on cardiovascular diseases (Kinsella et al. 1990) suggests it would be of benefit to increase such FA in milk.

Table 3 also illustrates the low transfer efficiency of $20: 5 n-3(9 \cdot 3 \%)$ and $22: 6 n-3(16 \cdot 2 \%)$ into milk-fat triacylglycerols. This finding contrasts with the values of 35-40\% obtained after post-rumen infusion (Hagemeister et al. 1988). A probable explanation relates to the partial, but significant, hydrogenation of the fish oil FA, demonstrated recently both in vivo and in vitro, as mentioned previously. Obviously, further research is needed to clarify the contradiction with negative findings in this respect (Ashes et al. 1992), as well as the surprising stimulatory effect of fish oil on rumen fibre digestion reported by Doreau \& Chilliard (1997a). As described for linoleic acid, an enrichment of linolenic acid in milk is possible using efficiently protected linseed, whereas the intake of unprotected linseed generally does not result in an increase in milk linolenic acid (Kennelly, 1996b).

\section{Trans-fatty acids}

An increase in the $18: 1$ content of milk fat is associated with an increase in trans-18:1 isomer content, a change considered of importance in human nutrition (Wolff, 1995). Indeed, human consumption of trans-18: 1 isomers has been shown to be related to the incidence of CHD (Willett et al. 1993), and dietary studies with human subjects have revealed their raising and lowering effects on LDL- and HDL-cholesterol respectively (Zock \& Katan, 1997). Dietary guidelines often stipulate that trans-FA intake should not increase (Truswell, 1995). In line with this situation, trans-FA content in margarines has been shown to have decreased in recent years (Precht \& Molkentin, 1997; Zock \& Katan, 1997). Using combined argentation TLC and $\mathrm{GC}$, it was recently established, however, that trans-18:1 isomers in milk fat predominantly comprise the trans-11 positional isomer, in line with the composition of rumen and duodenal contents (Precht \& Molkentin, 1995), although the trans-11 isomer represents more than $80 \mathrm{~mol} / 100 \mathrm{~mol}$ transmonoenes in rumen lipids but only $40-60 \mathrm{~mol} / 100 \mathrm{~mol}$ trans-monoenes in milk fat (Griinari et al. 1997). In partially-hydrogenated oils, however, amounts of the trans9, -10 and -11 isomers are almost equal. Also, evidence is available suggesting that the trans-FA present in milk and beef may not have the same negative characteristics as those present in partially-hydrogenated vegetable and fish oils (Willett et al. 1993; Zock \& Katan, 1997).

The highest levels of trans-18:1 in milk are found with diets containing fish oil and oils rich in linoleic acid, which are biohydrogenated in the rumen, and diets containing partially-hydrogenated oils which contain different trans18: 1 isomers. Surprisingly, Kalscheur et al. (1997) have observed an increase in trans-18:1 after feeding high-oleic sunflower oil, and attribute this effect to a sufficient amount of dietary linoleic acid available for biohydrogenation. The response of trans-18:1 content in milk to increasing levels of dietary linoleic acid has not been established. It can be hypothesized, however, that combining a high-concentrate diet with a supply of fish oil or oils rich in linoleic acid may enhance the production of trans-18:1 due to a slower rate of hydrogenation in the rumen.

Trans-isomers of 18:1 are considered to have a major role in the mechanisms for milk fat reduction described earlier, and there is a patent describing their use for the regulation of milk fat content and milk yield (Erdman et al. 1995). However, their concentration in milk fat does not always indicate a reduction in milk fat (Kalscheur et al. 1997). Recent work, summarized by Griinari et al. (1997), suggests that the production in the rumen of the trans-1018:1 isomer and its transfer to milk lipid is specifically responsible for the reduction in milk fat. The isomer would not be prevalent in the trans-18:1 mixture present in partlyhydrogenated fats. The occurrence of this isomer would be specifically associated with concentrate feeding, but not with roughage feeding.

\section{Increasing the conjugated linoleic acid content of milk}

The potent anti-carcinogenic properties of CLA have been widely shown using experimental animals and in epidemiological studies (Belury, 1995; McGuire et al. 1997). Among human foods, dairy products and beef are especially rich in CLA (Kelly \& Bauman, 1996). This specificity can be used to promote ruminant products, or at least limit the decrease in their consumption. Moreover, compared with milk, dairy products may have a higher content of CLA; processing may involve oxidation with free radical formation, followed by a reduction, yielding an increased CLA concentration (Lin et al. 1995). Four isomers have been found: cis-9 trans-11, cis-8 trans-10, cis-11 trans-13, cis-10 trans-12, the first isomer being quantitatively the most important. The comparative significance of these isomers for health remains to be established. Abomasal infusion of CLA caused an increase in both cis- and trans-isomers in milk CLA, showing a digestive origin (Chouinard et al. 1998b). However, a possible synthesis in the mammary gland from trans -11 by the $\Delta 9$-desaturase has been shown (Corl et al. 1998).

With winter diets not supplemented with lipids, the CLA content of milk is less than $1 \mathrm{mg} / 100 \mathrm{mg}$ total FA. Pasture significantly increases the CLA content. However, the more marked effect is associated with supplementary FA (Table 4). From these findings it is clear that (1) saturated and monounsaturated FA do not increase CLA; (2) the maximal 
Table 4. Effect of dietary lipids on concentration of conjugated linoleic acid (CLA) in milk (mg/100 mg total fatty acids)

\begin{tabular}{|c|c|c|c|}
\hline Reference & $C L A<0.8$ & CLA $0.8-1.6$ & CLA $>1.6$ \\
\hline Dhiman et al. (1997) & Raw and roasted cracked soyabeans & & $\begin{array}{l}\text { Soyabean oil } \\
\text { Linseed oil }\end{array}$ \\
\hline Kelly et al. (1997) & & $\begin{array}{l}\text { Peanut oil } \\
\text { Linseed oil }\end{array}$ & Sunflower oil \\
\hline Chilliard et al. (1999) & & & Fish oil \\
\hline Chouinard et al. (1998a) & $\begin{array}{l}\text { Untreated, roasted and micronized soyabeans } \\
\text { High-oil maize } \\
\text { Tallow }\end{array}$ & $\begin{array}{l}\text { Rapeseed Ca salts } \\
\text { Extruded soyabeans }\end{array}$ & $\begin{array}{l}\text { Soyabean Ca salts } \\
\text { Linseed Ca salts } \\
\text { Fish oil }\end{array}$ \\
\hline Dhiman et al. (1998) & $\begin{array}{l}\text { Extruded soyabeans } \\
\text { Extruded cottonseeds }\end{array}$ & & \\
\hline Griinari et al. (1998) & & $\begin{array}{l}\text { Sunflower oil } \\
\text { Rapeseed Ca salts }\end{array}$ & \\
\hline
\end{tabular}

increase in CLA is obtained with free oils rich in linoleic acid or salts of their FA, and in oils rich in $20: 5$ and $22: 6$; (3) a lower increase is obtained with oils rich in linolenic acid. A positive relationship between trans-18:1 and CLA was found by Lin et al. (1995) and Jiang et al. (1996). This finding is consistent with the highest values found with oils rich in linolenic acid and with fish oil, both of which induce large amounts of trans-18:1 FA. This finding may also explain why the effect of trans-18:1 is not always positively related to an increase in cardiovascular diseases (Wolff, 1995). However, it has been hypothesized that CLA may decrease butterfat content, independently of the positive relationship with trans-18:1 (Griinari et al. 1997).

\section{Control of adipose and muscle tissue lipids}

\section{Nature and development of fat depots}

In ruminants, lipids are mainly accumulated as triacylglycerols in adipocytes, located in subcutaneous, inter- and intramuscular adipose tissue, and abdominal, e.g. perirenal and omental fat depots. Total dissectable fat in a beef carcass varies approximately between 100 and $400 \mathrm{~g} / \mathrm{kg}$, about half of which is subcutaneous and intermuscular fat. With increasing animal weight, the proportion of subcutaneous fat increases more than that of intermuscular tissue, i.e. it has a higher relative (allometric) growth rate. Different regions of subcutaneous fat also grow at different rates, and the rate of increase in intramuscular lipid is less than that in dissectable fat (Wood, 1984). Young fat tissue has a high proportion of water and connective tissue and a low proportion of lipid, contained in small cells. When the animal gets older, fat depots, especially internal depots, increase mainly through an increase in cell size, with a decrease in the proportion of water and connective tissue in the tissue and a colour change from grey to more white. The fat cell diameter in adult animals may vary between 100 and $250 \mu \mathrm{m}$, indicating more than an eightfold difference in storage capacity (Lawrence \& Fowler, 1997). Female animals deposit more fat than males, and castration increases fat deposition so that there is a great emphasis on the production of entire males, especially in southern and western Europe.

Triacylglycerols in intramuscular adipocytes, associated with the epi- and endomysium, determine the 'marbling' of meat, which increases with the age of the animal. Lipid is also present, as intracellular lipid droplets, in muscle fibres, and at higher concentrations in red muscle than in white muscle. In addition to triacylglycerols in adipocytes and in oil droplets, intramuscular lipid also comprises the membrane phospholipids of the muscle fibres. Whereas extraction of the triacylglycerols can be done using nonpolar solvents such as diethyl ether, extraction of total lipids, including membrane phospholipids, requires the use of more polar solvents such as chloroform-methanol. Mean values calculated from data reported by Christie (1981), Larick \& Turner (1989), Ashes et al. (1995) and Gandemer (1997) show that FA in phosphatidyl choline and phosphatidyl ethanolamine make up 48.1 (SE 0.7) and 25.3 (SE 2.0) $\mathrm{mg} / 100 \mathrm{mg}$ total membrane phospholipid-bound FA respectively; $20-30 \%$ in each fraction being recovered as plasmologen analogues. It is claimed that total intramuscular lipid content is very important for sensory evaluation of beef, especially of texture and flavour. However, meat preparation and/or cultural differences have a considerable effect on sensory evaluation, since minimal intramuscular fat contents for optimal sensory quality vary between 15 and $30 \mathrm{~g} / \mathrm{kg}$ for Denmark and the US respectively (Wood, 1990). With decreasing total intramuscular lipid content, the relative importance of phospholipids in total lipids increases. Indeed, as adipocyte size is lowered, or less adipocytes are present, amounts of muscle fibre membranes remain relatively constant.

\section{Breed and conformation effects on adipose tissue distribution}

There are important breed differences in the proportions of body fat in the various depots. Breeds noted for beef production have a higher value for dissectable: intramuscular fat than breeds noted for milk production, as shown in Table 5, 
Table 5. Carcass and intramuscular fat content of Holstein, double-muscled (DM) and dual-purpose (M) Belgian Blue (BB) cattle fed on different diets

\begin{tabular}{|c|c|c|c|}
\hline Reference & Animals and diets & Dissectable fat in carcass $(\mathrm{g} / \mathrm{kg})$ & Intramuscular fat in longissimus thoracis ${ }^{*}(\mathrm{~g} / \mathrm{kg})$ \\
\hline \multirow[t]{3}{*}{ Fiems et al. (1998) } & DM BB bulls of about $700 \mathrm{~kg}$ & & \\
\hline & High-energy & 131 & $9 \cdot 3$ \\
\hline & Low-energy & 123 & $8 \cdot 6$ \\
\hline \multirow[t]{8}{*}{ Minet et al. (1996) } & Bulls of about $500-550 \mathrm{~kg}$ & & \\
\hline & Holstein & 252 & $46 \cdot 4$ \\
\hline & MBB & 242 & $22 \cdot 0$ \\
\hline & DM BB & 116 & 7.5 \\
\hline & DM BB bulls of about $600 \mathrm{~kg}$ & & \\
\hline & Control: Alone & 134 & $6 \cdot 8$ \\
\hline & + Milk fat & 137 & 8.8 \\
\hline & + Vegetable fat & 149 & $11 \cdot 2$ \\
\hline Webb et al. (1998) & DM BB cows of about $700 \mathrm{~kg}$ & 126 & $11 \cdot 2$ \\
\hline
\end{tabular}

* Extracted with chloroform-methanol in Webb et al. (1998); determined by near i.r. reflectance spectroscopy in Fiems et al. (1998); procedure not mentioned in Minet et al. (1996).

also illustrating the low intramuscular fat content of doublemuscled Belgian Blue cattle compared with Holstein cattle.

Furthermore, the subcutaneous fat: dissectable fat value increases with meat yield. For the same degree of subjective EU carcass fatness classification (e.g. 2; EEC, 1981, 1991), based to a large extent on visual inspection of the subcutaneous fat cover, the carcass dissectable fat content, estimated by dissection of a one-rib cut, decreased with increasing conformation, the EU classification of muscularity (EEC, 1981, 1991), from 200 to $123 \mathrm{~g} / \mathrm{kg}$. This finding suggests that the relative importance of subcutaneous tissue in total adipose tissue increases with increasing muscularity (G Van de Voorde, S De Smet and DI Demeyer, unpublished results).

\section{Fatty acid composition}

Beef lipid composition, as well as that of milk fat, reflects rumen metabolism of dietary lipids. Relative amounts of 'unusual' odd-chain, branched-chain and trans-monoenoic acids of $3 \cdot 3,2.7$ and $4.2 \mathrm{~mol} / 100 \mathrm{~mol}$ total FA respectively have been reported. The multi-branched FA pristanic and phytanic acids are present, whereas the trans-18:1 series is dominated by the trans-11 isomer (Christie, 1981). Beef meat and beef tallow display slightly higher relative proportions of trans-10- and trans-11-18:1 (approximately $65 \mathrm{~mol} / 100 \mathrm{~mol}$ total trans-18:1 isomers, which represent 4.9 (SD 0.9) mol/100 mol total FA) compared with butterfat (55-60 mol/100 mol total trans-18: 1 isomers), the opposite being found for trans-13- and trans-16-isomers. This finding would indicate that some subtle differences exist in the metabolic selectivity for individual trans-18:1 acids between the mammary gland and muscles or adipose tissue (Bayard \& Wolff, 1996). In earlier work, the same group reported higher trans-18:1 contents in total FA for beef tallow $(4.6 \mathrm{~mol} / 100 \mathrm{~mol})$ than for meat $(1.95 \mathrm{~mol} / 100 \mathrm{~mol})$. Intramuscular trans-18:1 was concentrated in triacylglycerol-FA $(2.53 \mathrm{~mol} / 100 \mathrm{~mol})$, and much less in polar lipid FA (0.76 mol/100 mol; Wolff, 1995).

Saturated and unsaturated aldehydes, possibly derived metabolically from FA, have been detected in adipose tissue from ruminants, and some of these may be important in flavour determination of meat and meat products (Christie, 1981). It is generally recognized that beef fat has a more saturated nature than pork and poultry fat, because of the biohydrogenation processes in the rumen (Demeyer et al. 1995a). This statement cannot be generalized, however. There are, for example, clear indications of specific deposition and/or metabolism (desaturation) of absorbed FA in the various triacylglycerol depots. As in all large animals, internal fat depots in mature animals are characterized by high proportions of saturated FA. Saturation, characterized by the $18: 0 / 18: 1$ value, decreases with decreasing distance from the animal's exterior. Effects of temperature differences between these sites on desaturase activity are held partly responsible for this finding. In contrast to pigs, the concentration of saturated acids in fat depots decreases with age and body fat content in cattle (Wood, 1984). This finding seems to be limited to domesticated cattle, however, as adipose tissue triacylglycerols of lean African wild ruminants were found to contain higher proportions of unsaturated FA, possibly because of dietary differences (Sinclair \& O'Dea, 1990). Effects of breed are illustrated by the more saturated character of Hereford cow subcutaneous adipose tissue compared with that of Brahman cows (Huerta-Leidenz et al. 1993). The effect of site is illustrated for double-muscled animals in Table 6.

The data in Table 6 also illustrate that the triacylglycerol fraction of intramuscular lipids shows a FA composition similar to that of subcutaneous fat. The phospholipid fraction on the other hand is probably fairly representative of the membrane structure and is characterized by high levels of PUFA, particularly linoleic and arachidonic acids. In fact, skeletal muscle appears to be a major repository for these essential FA in ruminants (Christie, 1981). Concentrations of total FA in the M. longissimus thoracis increased with increasing carcass fat content ( $r$ 0.41), the increase being limited to the triacylglycerol fraction, a finding also illustrating the distinctive nature of the polar lipid fraction. The concentration of FA in the latter amounts to $3.1 \mathrm{mg} / \mathrm{g}$ wet tissue, a value similar to those reported by Larick \& Turner (1989) and Gandemer (1997). The PUFA 
Table 6. Fatty acid (FA) composition (mg/100 mg FA) of muscle and adipose tissue lipids of double-muscled Belgian Blue cows (Webb et al. 1998)

\begin{tabular}{|c|c|c|c|c|c|c|}
\hline \multirow[b]{2}{*}{ FA } & \multicolumn{2}{|c|}{ Intramuscular fat } & \multicolumn{2}{|c|}{ Intermuscular fat } & \multirow[b]{2}{*}{ Perirenal fat } & \multirow[b]{2}{*}{ Subcutaneous fat } \\
\hline & $\operatorname{PL}(3 \cdot 1)^{*}$ & $\operatorname{TAG}(8 \cdot 1)^{*}$ & M. serratus & M. transversalis & & \\
\hline $14: 0$ & $0 \cdot 25$ & $2 \cdot 15$ & $2 \cdot 52$ & $2 \cdot 17$ & $2 \cdot 21$ & $2 \cdot 62$ \\
\hline $16: 0$ & 14.61 & $27 \cdot 19$ & 25.98 & $25 \cdot 43$ & $23 \cdot 71$ & 27.41 \\
\hline $16: 1$ & $2 \cdot 87$ & 3.35 & $2 \cdot 86$ & $1 \cdot 88$ & 1.44 & 3.99 \\
\hline $18: 0$ & $12 \cdot 58$ & $16 \cdot 12$ & 18.08 & $25 \cdot 74$ & $30 \cdot 82$ & $12 \cdot 79$ \\
\hline $18: 1$ & $19 \cdot 11$ & $43 \cdot 10$ & $42 \cdot 17$ & 36.67 & 34.02 & 44.80 \\
\hline $18: 2$ & $23 \cdot 10$ & 2.44 & $2 \cdot 33$ & 2.49 & $2 \cdot 41$ & $2 \cdot 21$ \\
\hline $18: 3$ & 3.57 & 0.63 & 0.73 & 0.79 & 0.71 & 0.71 \\
\hline $20: 4$ & $5 \cdot 88$ & 0.00 & - & - & - & - \\
\hline Other & $18 \cdot 03$ & $5 \cdot 02$ & $5 \cdot 34$ & $4 \cdot 82$ & 4.69 & 5.46 \\
\hline
\end{tabular}

* mg FA/g wet tissue; PL, polar lipids; TAG, triacylglycerols.

content in the polar lipids $(32.6 \mathrm{mg} / 100 \mathrm{mg})$ is similar to recent values reported for beef $(21.5-38.7 \mathrm{mg} / 100 \mathrm{mg})$, as well as for pork $(29.9-38.7 \mathrm{mg} / 100 \mathrm{mg}$; Demeyer et al. $1995 a)$.

Because of the low content of total intramuscular lipid, its FA composition is determined to a large extent by that of the polar lipid fraction and is similar to that of pork intramuscular lipids, characterized by high and low contents of PUFA and trans-FA respectively, an important finding from a nutritional point of view. In summary, dissectable fat of lean animals is more saturated than that of fat animals, whereas the opposite is true for intramuscular fat.

\section{Effects of fat feeding}

Unlike milk production, lean beef production is not limited by energy intake. However, fats may be cheaper alternatives in feed formulation, and their use allows modification of beef FA composition, providing other incentives for the increasing practice of fat supplementation in beef production. From a literature survey, Clinquart et al. (1995) conclude that, in general, fat addition to a finishing diet results in improved weight gain at lower intakes associated with a 5-15\% higher fat content of the carcasses. At incorporation levels higher than $5 \%$, however, growth may be impaired, possibly related to impairments in both digestion and intake; the authors cite two non-published experiments from their laboratory, however, in which

Table 7. Percentage change in fatty acid (FA) composition of perirenal and intramuscular (Iongissimus thoracis) fat by dietary addition of soyabean oil $(33 \mathrm{~g} / \mathrm{kg})$ or heat-treated soyabeans $(150 \mathrm{~g} / \mathrm{kg})$ (Clinquart et al. 1995)

\begin{tabular}{lccccc}
\hline & \multicolumn{2}{c}{ Soyabean oil } & & \multicolumn{2}{c}{ Heat-treated soyabeans } \\
\cline { 2 - 3 } \cline { 5 - 6 } FA & Perirenal & Intramuscular & & Perirenal & Intramuscular \\
\hline SMCFA & -21.2 & $-10 \cdot 8$ & & -3.8 & -1.5 \\
$18: 0$ & +2.0 & $+3 \cdot 8$ & & -2.2 & $-2 \cdot 2$ \\
$18: 1$ & $+34 \cdot 1$ & +2.3 & & +5.5 & +2.1 \\
$18: 2$ & -8.7 & $+7 \cdot 1$ & & +4.5 & +3.8 \\
\hline
\end{tabular}

SMCFA, short- and medium-chain FA. decreases in carcass fat content of up to $28 \%$ were observed. This finding might be explained by inhibitions of de novo FA synthesis, as reported with dairy cattle. From their own results, summarized in Table 7 , it is clear that unsaturated oils provoke effects comparable with those observed in milk fat: a decrease in short- and medium-chain FA content, and an increase in long-chain FA, mainly $18: 1$. These effects are less pronounced in intramuscular lipids and with heat-treated beans $v$. free oils. With free oil $18: 2$ is preferentially retained in intramuscular lipids, again reflecting the separate metabolic importance of muscle polar lipids. Heat treatment of soyabeans seems to protect 18:2 from biohydrogenation, as discussed earlier. As with dairy cattle, evidence is available suggesting that fat supplementation induces effects beyond changes in the proportion of dietary and newly-synthesized FA as substrates for fat synthesis. Van Eenaeme et al. (1991) have shown, for example, that fat supplementation increased plasma insulin levels with a reduction in blood glucose levels.

It is more difficult to justify dietary interventions to change the FA composition of beef fat than it is for milk fat. Indeed, beef dissectable fat is not consumed directly and is used as tallow in food and non-food industries. Furthermore, intramuscular FA composition has been shown to display a favourable PUFA content in very lean animals (Webb et al. 1998). The further development of lean animals with low intramuscular fat content seems to deserve more support than dietary intervention. Management of feeding may also contribute to a better partitioning of fat deposition. Feeding animals at low intake levels, followed by re-alimentation, increases the proportion of subcutaneous lipid, at the expense of intramuscular lipid (Hornick et al. 1998). However, as it seems that the very low intramuscular lipid levels of about $10 \mathrm{~g} / \mathrm{kg}$ may impair sensory quality, a higher content of intramuscular triacylglycerols enriched in PUFA through dietary means may be a goal to pursue further. Also in the intramuscular lipid of very lean animals, an improvement in the $n-3: n-6$ PUFA value may be suggested. In contrast to milk, sheep muscle intramuscular lipids specifically retained $n$-3 PUFA (20:5 n-3 and 22:6n-3), added to the diet as a rumen-inert fish oil preparation (Ashes et al. 1992). The $n-3: n-6$ value was increased from a control value of $0 \cdot 20$ to $0 \cdot 54$. Such changes are observed mainly, or 
only, in the phospholipid fraction, whereas little or no $n-3$ PUFA are retained in the triacylglycerols, in contrast to pigs (Wood \& Enser, 1997). Chain elongation occurs since dietary linseed oil also increases $20: 5 n-3$ in intramuscular total lipids and phospholipids (Vatansever et al. 1998). On the other hand, it has been clearly shown that linseed oil supplementation increases $18: 3 n-3$ in adipose tissues (Clinquart et al. 1991). In more detailed work, Ashes et al. (1995) discuss the specific substitution of 20:5 for 20:4 in the phosphatidyl inositol of membrane phospholipids. They refer to the associated changes to be expected in the nature and effects of phosphatidyl inositol-derived secondary messenger molecules. In a more general approach, these effects include possible changes in gene expression (Jump et al. 1996) and immune reactions (Miles \& Calder, 1998), mediated through altered prostaglandins and leukotrienes, when muscle membrane PUFA are modified. As discussed for milk production, such considerations, also related to animal welfare, should be taken into account when evaluating methods for dietary manipulation of muscle lipids. They should be of similar importance to considerations of the greater susceptibility to oxidation and flavour defects of PUFA-enriched meat and meat products (Gandemer, 1997). Similar considerations should indeed apply for further selection and breeding of double-muscled cattle (Demeyer et al. 1995b).

The use of tissue active growth promoters as well as direct immunological depression of body fat (Flint et al. 1994) will not be discussed here. Indeed, regulatory and/or consumer attitudes do not (yet) allow such technologies. Also, they may adversely affect sensory meat quality (Fiems et al. 1990).

Finally, it should be realized that, as was observed for milk production, simple feeding practices may go a long way towards optimizing beef FA composition. From data presented by Wood \& Enser (1997), $n-3: n-6$ values for PUFA in intramuscular lipids of 0.12 to 0.77 can be calculated for concentrate- and grass-fed cattle respectively. This finding suggests that the higher level of $18: 3 n-3$ normally found in meat compared with milk is due to a more efficient incorporation into intramuscular lipids than into milk lipids rather than to the concentrate feeding of fattening animals. The difference, however, was partly due to a lower 18:2 meat content for the concentrate-fed animals (Enser et al. 1998)

\section{Limits to modification of ruminant fat}

Processing of feed for fat protection may not be acceptable to consumers or governments, as illustrated by the refusal to accept formaldehyde treatment, in spite of extensive experimentation (McDonald \& Scott, 1977). The same argument may hold for newer technologies involving the preparation of fatty acyl amides. The use of feed additives aimed at modification of milk production is, at least for the EU, out of the question. A good example is monensin, shown to depress milk fat (Cant et al. 1997; Van Amburgh, 1997) and to increase duodenal flow of unsaturated FA (Kobayashi et al. 1992). A definite ban of its use could be supported by the finding that it is absorbed from the intestinal tract and elicits a series of metabolic effects in the animal when infused intravenously (Armstrong \& Spears, 1988). Consumer and governmental aversion is even greater against the use of production modifiers active at the animal tissue level, although reduction of short- and medium-chain FA and increases in long-chain FA in milk fat have been achieved in cows treated with bovine somatotropin (Baer, 1996). Direct interference with mammary tissue metabolism through genetic manipulation has been suggested for reduction of acetyl-CoA carboxylase, the enzyme regulating de novo synthesis of fat (Chalupa et al. 1996). A detailed proposal for the development of a recombinant bovine stearoyl-CoA desaturase (EC 1.14.99.5) for use in selection and/or treatment of milk subsequent to its removal from the cow is available (McFadden \& Trumble, 1997). Again, consumer acceptance of such technologies is questionable. The limitation on the use of tallows in the UK because of the risk of transmission of factors linked to bovine spongiform encephalopathy is perhaps the best example of the care that should be taken when proposing dietary or other interventions. In an excellent paper that should inspire animal production as a whole, Fredeen (1996) states that modification of milk composition via nutrition should not be approached simply from the point of view of economic advantage. Environmental, welfare and moral considerations should also be considered, analogous to a general quality concept for animal production (Demeyer, 1997). For example, dietary supplements should also be evaluated for environmental effects related to, for example, methanogenesis (Dong et al. 1997), whereas the role of pasture $v$. concentrate feeding in providing more acceptable unsaturation of milk fat (Murphy et al. 1995) and improvement of PUFA-derived flavour compounds in dairy products (Urbach, 1990) should perhaps receive more attention, related also to the need for extensification. Finally, the greater susceptibility to oxidation and flavour defects of dairy products enriched in PUFA should be considered (Doreau \& Chilliard, 1997b; Doreau et al. 1997).

\section{Acknowledgements}

The authors thank D. Baeyens, J. Chabrot, A. Christophe, W. De Greyt, S. De Smet, R. De Schrijver, L. Fiems, V. Fievez, J.L. Hornick, L. Istasse, E. Teller, J. Van Camp and C. Van Nevel for help with the literature search, interpretation of data and preparation of the manuscript. Part of the work reported by D. D. was supported by the IWONL, Ministry of Agriculture, Brussels.

\section{References}

Armstrong JD \& Spears JW (1988) Intravenous administration of ionophores in ruminants: effects on metabolism independent of the rumen. Journal of Animal Science 66, 1807-1817.

Ashes JR, Fleck E \& Scott TW (1995) Dietary manipulation of membrane lipids and its implication for their role in the production of second messengers. In Ruminant Physiology: Digestion, Metabolism, Growth and Reproduction, pp. 373-386 [W van Engelhardt, S Leonhard-Marek, G Breves and D Giesecke, editors]. Stuttgart: Ferdinand Enke Verlag. 
Ashes JR, Siebert BD, Gulati SK, Cuthbertson AZ \& Scott TW (1992) Incorporation of $n-3$ fatty acids of fish oil into tissue and serum lipids of ruminants. Lipids 27, 629-631.

Baer RJ (1996) Production and utilisation of dairy cow's milk and products with increased unsaturated fatty acids. In Progress in Dairy Science, pp. 247-261 [CJC Phillips, editor]. New York: $\mathrm{CAB}$ International.

Bauchart D, Legay-Carmier F, Doreau M \& Gaillard B (1990) Lipid metabolism of liquid-associated and solid-adherent bacteria in rumen contents of dairy cows offered lipidsupplemented diets. British Journal of Nutrition 63, 563-578.

Bayard CC \& Wolff RL (1996) Analysis of trans-18:1 isomer content and profile in edible refined beef tallow. Journal of the American Oil Chemists Society 73, 531-533.

Belury MA (1995) Conjugated dienoic linoleate: a polyunsaturated fatty acid with unique chemoprotective properties. Nutrition Reviews 53, 83-99.

Brockerhoff H (1966) Fatty acid distribution patterns of animal depot fats. Comparative Biochemistry and Physiology 19, 1-12.

Butantu M (1996) La supplémentation lipidique chez la vache laitière (Lipid supplementation in dairy cows). PhD Thesis, University of Louvain-la-Neuve, France.

Cant JP, Fredeen AH, MacIntyre T, Gunn J \& Crowe N (1997) Effect of fish oil and monensin on milk composition in dairy cows. Canadian Journal of Animal Science 77, 125-131.

Chalupa W, Calligan DT \& Ferguson JD (1996) Animal nutrition and management in the 21st century. Animal Feed Science and Technology 58, 1-18.

Chilliard Y, Chardigny JM, Chabrot J, Ollier A, Sebedio J-L \& Doreau M (1999) Effects of ruminal or postruminal fish oil supply on conjugated linoleic acid (CLA) content of cow milk fat. Proceedings of the Nutrition Society 58, 70A.

Chouinard PY, Corneau L, Bauman DE, Butler WR, Chilliard Y \& Drackley K (1998a) Conjugated linoleic acid content of milk from cows fed different sources of dietary fat. Journal of Dairy Science 81, Suppl. 1, 233.

Chouinard PY, Corneau L, Bauman DE, Metzger LE \& Barbano DM (1998b) Milk yield and composition during abomasal infusion of conjugated linoleic acid in dairy cows. Journal of Dairy Science 81, Suppl. 1, 353.

Chouinard PY, Girard V \& Brisson GJ (1997) Performance and profiles of milk fatty acids of cows fed full fat, heat-treated soybeans using various processing methods. Journal of Dairy Science 80, 334-342.

Christie WW (editor) (1981) The composition, structure and function of lipids in the tissues of ruminant animals. In Lipid Metabolism in Ruminant Animals, pp. 95-191. Oxford: Pergamon Press.

Claus R (1991) Meat and consumer preferences in Europe: demography, marketing issues. In The European Meat Industries in the 1990's, pp. 217-246 [FJM Smulders, editor]. Utrecht: ECCEAMST.

Clinquart A, Istasse L, Dufrasne I, Mayombo A, Van Eenaeme C \& Bienfait J-M (1991) Effects on animal performance and fat composition of two fat concentrates in diets for growingfattening bulls. Animal Production 53, 315-320.

Clinquart A, Micol D, Brundseaux C, Dufrasne I \& Istasse L (1995) Utilisation des matières grasses chez les bovins l'engraissement (Utilization of fat concentrates for fattening cattle). INRA Productions Animales 8, 29-42.

Corl BA, Chouinard PY, Bauman DE, Dwyer DA, Griinari JM \& Nurmela KV (1998) Conjugated linoleic acid in milk fat of dairy cows originates in part by endogenous synthesis from trans-11 octadedenoic acid. Journal of Dairy Science 81, Suppl. $1,233$.

Deffense E (1993) Milk fat fractionation today: a review. Journal of the American Oil Chemists Society 70, 1193-1201.
Demeyer D (1973) Lipidstoffwechsel im Pansen (Lipid metabolism in the rumen). In Biologie und Biochemie der Mikrobiellen Verdaunn (Biology and Biochemistry of Microbial Digestion), pp. 209-234 [D Giesecke and H Henderickx, editors]. Munchen: BL Verslaggesellschaft.

Demeyer D (1997) An introduction to the OECD programme: meat quality and the quality of animal production. Food Chemistry $\mathbf{5 9}$, 491-497.

Demeyer D, Buysse G \& Fiems L (1995a) Meat quality in double muscled animals. In Composition of Meat in Relation to Processing, Nutritional and Sensory Quality, pp. 95-102 [K Lundström, I Hansson and E Wiklund, editors]. Utrecht: ECCEAMST.

Demeyer D \& Van Nevel C (1995) Transformations and effects of lipids in the rumen: three decades of research at Gent University. Archives of Animal Nutrition 48, 119-134.

Demeyer D, Van Nevel C \& Fiems L (1995b) Nutritional engineering of beef fat composition: motive, target and approach. In Composition of Meat in Relation to Processing, Nutritional and Sensory Quality, pp. 15-36 [K Lundström, I Hansson and E Wiklund, editors]. Utrecht: ECCEAMST.

Demeyer DI, Henderson C \& Prins R (1978) Relative significance of exogenous and de novo synthesized fatty acids in the formation of rumen microbial lipids in vitro. Applied and Environmental Microbiology 35, 24-30.

Demeyer DI \& Hoozee J (1984) Schatting van linolzuursynthese in de pens van een schaap bij eiwit- en vetvrije voedering (Estimation of linoleic acid synthesis in the rumen of a sheep fed a protein and fat free diet). Proceedings van de 9de Studiedag voor Nederlandstalige Voedingsonderzoekers (Proceedings of 9th Meeting of Dutch Speaking Nutritionists), Utrecht, pp. 27-29. Vakgroep Zoötechniek: University of Utrecht.

DePeters EJ, Medrano JF \& Reed BA (1995) Fatty acid composition of milk fat from three breeds of dairy cattle. Canadian Journal of Animal Science 75, 267-269.

Dhiman TR, Helmink ED, McMahon DJ, Fife RL \& Pariza MW (1998) Conjugated linoleic acid content of milk from cows fed extruded oilseeds. Journal of Dairy Science 81, Suppl. 1, 353.

Dhiman TR, Satter LD, Pariza MW, Galli MP \& Albright K (1997) Conjugated linoleic acid (CLA) content of milk from cows offered diets rich in linoleic and linolenic acid. Journal of Dairy Science 80, Suppl. 1, 184.

Dong Y, Bae HD, McAllister TA, Mathiso GW \& Cheng KJ (1997) Lipid-induced depression of methane production and digestibility in the artificial rumen system. Canadian Journal of Animal Science 77, 269-278.

Doreau M \& Chilliard Y (1997a) Effects of ruminal or postruminal fish oil supplementation on intake and digestion in dairy cows. Reproduction Nutrition Développement 37, 113-124.

Doreau M \& Chilliard Y (1997b) Digestion and metabolism of dietary fat in farm animals. British Journal of Nutrition 78, Suppl. 1, S15-S35.

Doreau M, Demeyer DI \& Van Nevel CJ (1997) Transformation and effects of unsaturated fatty acids in the rumen. Consequences on milk fat secretion. In Milk Composition, Production and Biotechnology, pp. 73-92 [RAS Welch, DJW Burns, SR Davis, AI Popay and CG Prosser, editors]. New York: CAB International.

EEC (1981) Council Regulation (EEC) no. 1208/81 of 28 April 1981 Determining the Community Scale for the Classification of Carcases of Adult Bovine Animals. Strasbourg: EEC.

EEC (1991) Council Regulation (EEC) no. 1026/91 of 22 April 1991 Amending Regulation (EEC) no. 1208/81 Determining the Community Scale for the Classification of Carcases of Adult Bovine Animals. Strasbourg: EEC.

Enjalbert F, Nicot MC, Vernay M, Moncoulon R \& Griess D (1994) Effect of different forms of polyunsaturated fatty acids on 
duodenal and serum fatty acid profiles in sheep. Canadian Journal of Animal Science 74, 595-600.

Enser M, Hallet KG, Hewett B, Fursey GAJ, Wood JD \& Harrington G (1998) Fatty acid content and composition of UK beef and lamb muscle in relation to production system and implications for human nutrition. Meat Science 49, 329-341.

Erdman RA, Teter BT, Keeney M \& Sampugna J (1995) Method for regulating milk fat and milk production using trans-fatty acids. United States Patent 5, 416, 115.

Fellner V, Sauer FD \& Kramer JKG (1995) Steady-state rates of linoleic acid biohydrogenation by ruminal bacteria in continuous culture. Journal of Dairy Science 78, 1815-1823.

Fellner V, Sauer FD \& Kramer JKG (1997) Effect of nigericin, monensin, and tetronasin on biohydrogenation in continuous flow-through ruminal fermenters. Journal of Dairy Science $\mathbf{8 0}$, 921-928.

Ferlay A, Chilliard Y \& Doreau M (1992) Effects of calcium salts differing in fatty acid composition on duodenal and milk fatty acid profiles in dairy cows. Journal of the Science of Food and Agriculture 60, 31-37.

Fiems LO, Buts B, Boucqué Ch V, Demeyer DI \& Cottyn BJ (1990) Effect of a $\beta$-agonist on meat quality and myofibrillar protein fragmentation in bulls. Meat Science 27, 29-39.

Fiems LO, de Campeneere S, Bogaerts DF, Cottyn BG \& Boucqué Ch V (1998) The influence of dietary energy and protein levels on performance, carcass and meat quality of Belgian White-blue double-muscled finishing bulls. Animal Science 66, 319-327.

Flachowski G \& Jahreis G (1997) Fettsäurenaufnahme des Menschen und Möglichkeiten der Beeinflussung durch die Tierenährung (Fatty acid intake in man and possibilities of influence by animal foods). Fett/Lipid 99, 106-115.

Flint DJ, Cryer A, Kestin S, Griffin H, Butterwith S, Rhind S, Futter C, Tonner E, Kennedy R, Cryer J \& Marsh J (1994) Manipulation of body fat using antibodies raised against plasma membrane antigens of adipocytes. In Vaccines in Agriculture, pp. 129-135 [PR Wood, P Willadse, JE Vercoe, RM Hoskinson and D Demeyer, editors]. Melbourne: CSIRO Information Services.

Fredeen AH (1996) Considerations in the nutritional modification of milk composition. Animal Feed Science and Technology 59, $185-197$.

Gandemer G (1997) Lipides du muscle et qualité de la viande. Phospholipides et flaveur (Muscle lipid and meat quality. Phospholipids and flavour). Oléagineux-Corps gras-Lipides $\mathbf{4}$, $19-25$.

Gaynor PJ, Erdman RA, Teter BB, Capuco AV \& Waldo DR (1996) Glucose and norepinephrine challenges during abomasal infusion of cis or trans octadecenoates in Holstein cows. Journal of Dairy Science 79, 1590-1596.

Gaynor PJ, Erdman RA, Teter BB, Sampugna J, Capuco AV, Waldo DR \& Hamosh M (1994) Milk fat yield and composition during abomasal infusion of cis or trans octadecanoates in Holstein cows. Journal of Dairy Science 77, 157-165.

Gerson T, John A \& King ASD (1985) The effects of dietary starch and fibre on the in vitro rates of lipolysis and hydrogenation by sheep rumen digesta. Journal of Agricultural Science, Cambridge 105, 97-101.

Gormley TR, Downey G \& O'Beirne D (1987) Food, Health and the Consumer. London: Elsevier Applied Sciences.

Griinari JM, Chouinard PY \& Bauman DE (1997) Trans fatty acid hypothesis of milk fat depression revised. In Proceedings of the Cornell Nutrition Conference for Feed Manufacturers, pp. 208-216. Ithaca, NY: Cornell University Press.

Griinari JM, Nurmela K, Sairanen A, Nousiainen JI \& Khalili H (1998) Effect of dietary sunflower oil and pasture forage maturity on conjugated linoleic acid (CLA) content in milk fat from lactating dairy cows. Journal of Dairy Science 81, Suppl. 1, 300.
Grummer RR (1988) Influence of prilled fat and calcium salts of palm oil fatty acids on ruminal fermentation. Journal of Dairy Science 71, 117-123.

Gulati SK, Scott TW \& Ashes JR (1997) In-vitro assessment of fat supplements for ruminants. Animal Feed Science and Techno$\operatorname{logy}$ 64, 127-132.

Gurr MI \& James AT (editors) (1980) The biochemistry of fatty acids. In Lipid Biochemistry, pp. 25-87. New York: Chapman \& Hall.

Hagemeister H, Precht D \& Barth CA (1988) Studies on the transfer of omega-3 fatty acids into bovine milk fat. Milchwissenschaft 43, 153-158.

Hansen HO \& Knudsen J (1987) Effect of exogenous long-chain fatty acids on lipid biosynthesis in dispersed ruminant mammary gland epithelial cells: esterification of long-chain exogenous fatty acids. Journal of Dairy Science 70, 1344-1349.

Harfoot CG \& Hazlewood GP (1997) Lipid metabolism in the rumen. In The Rumen Microbial Ecosystem, pp. 382-426 [PN Hobson and CS Stewart, editors]. Glasgow: Blackie Academic \& Professional.

Hornick JL, Van Eenaeme C, Clinquart A, Diez M \& Istasse L (1998) Different periods of feed restriction before compensatory growth in Belgian Blue bulls: I. Animal performance, nitrogen balance, meat characteristics, and fat composition. Journal of Animal Science 76, 249-259.

Huerta-Leidenz NO, Cross HR, Savell JW, Lunt DK, Naker JF, Pelton LS \& Smith SB (1993) Comparison of the fatty acid composition of subcutaneous adipose tissue from mature Brahman and Hereford cows. Journal of Animal Science 71, 625-630.

Hussein HS, Merchen NR \& Fahey GC (1995) Composition of ruminal bacteria harvested from steers as influenced by dietary forage level and fat supplementation. Journal of Animal Science 73, 2469-2473.

Huyghebaert A, Verhaeghe D \& De Moor H (1994) Fat products using chemical and enzymatic interesterification. In Fats in Food Products, pp. 319-345 [DPJ Moran and KK Rajah, editors]. Glasgow: Blackie Academic and Professional.

Immig I, Van Nevel C \& Demeyer DI (1993) Lipolysis and hydrogenation of soyabean oil in the rumen of sheep. In Proceedings of the Society of Nutrition Physiology, vol. 1, p. 59 [D Giesecke, editor]. Frankfurt: DLG-Verlag.

Ip C \& Marshall JR (1996) Trans fatty acids and cancer. Nutrition Reviews 54, 138-145.

Jenkins TC (1994) Regulation of lipid metabolism in the rumen. Journal of Nutrition 124, 1372S-1376S,

Jenkins TC, Bateman HG \& Block SM (1996) Butylsoyamide increases unsaturation of fatty acids in plasma and milk of lactating dairy cows. Journal of Dairy Science 79, 585-590.

Jiang J, Bjoerck L, Fondén R \& Emanuelson M (1996) Occurrence of conjugated cis-9, trans-11-octadecadienoic acid in bovine milk: effects of feed and dietary regimen. Journal of Dairy Science 79, 438-445.

Jump DB, Clarke SD, Thelen A, Liimatta M, Ren B \& Badin M (1996) Dietary polyunsaturated fatty acid regulation of gene transcription. Progress in Lipid Research 35, 227-241.

Kalscheur KF, Teter BB, Piperova LS \& Erdman RA (1997) Effect of fat source on duodenal flow of trans- $\mathrm{C}_{18: 1}$ fatty acids and milk fat production in dairy cows. Journal of Dairy Science 80, 21152126.

Kelly ML \& Bauman DE (1996) Conjugated linoleic acid: a potent anticarcinogen found in milk fat. In Proceedings of the Cornell Nutrition Conference for Feed Manufacturers, pp. 68-74. Ithaca, NY: Cornell University Press.

Kelly ML, Berry JR, Dwyer DA, Bauman DE, Van Amburgh ME \& Griinari JM (1997) Effect of dietary fatty acid sources on 
conjugated linoleic acid (CLA) levels in milk from lactating dairy cows. Journal of Dairy Science 80, Suppl. 1, 243.

Kennelly JJ (1996a) Producing milk with $2.5 \%$ fat - the biology and health implications for dairy cows. Animal Feed Science and Technology 60, 161-180.

Kennelly JJ (1996b) The fatty acid composition of milk fat as influenced by feeding oilseeds. Animal Feed Science and Technology 60, 137-152.

Kinsella JE, Lokesh B \& Stone RA (1990) Dietary $n-3$ polyunsaturated fatty acids and amelioration of cardiovascular disease: possible mechanisms. American Journal of Clinical Nutrition 52, 1-28.

Kobayashi Y, Wakita M \& Hoshino S (1992) Effects of the ionophore salinomycin on nitrogen and long-chain fatty acids profiles of digesta in the rumen and duodenum of sheep. Animal Feed Science and Technology 36, 67-76.

Larick DK \& Turner BE (1989) Influence of finishing diet on the phospholipid composition and fatty acid profile of individual phospholipids in lean muscle of beef cattle. Journal of Animal Science 67, 2282-2293.

Lawrence TLJ \& Fowler VR (1997) Growth of Farm Animals. New York: CAB International.

Lin H, Boylston D, Chang MJ, Luedecke LO \& Shultz TD (1995) Survey of the conjugated linoleic acid contents of dairy products. Journal of Dairy Science 78, 2358-2365.

McDonald IW \& Scott TW (1977) Foods of ruminant origin with elevated content of polyunsaturated fatty acids. World Review of Nutrition and Dietetics 26, 144-207.

McFadden T \& Trumble W (1997) OECD Project Report. Paris: OECD.

McGuire MA, McGuire MK, McGuire MS \& Griinari JM (1997) Bovinic acid: the natural CLA. In Proceedings of the Cornell Nutrition Conference for Feed Manufacturers, pp. 217-226. Ithaca, NY: Cornell University Press.

Mansbridge RJ \& Blake JS (1997) Nutritional factors affecting the fatty acid composition of bovine milk. British Journal of Nutrition 78, Suppl. 1, S37-S47.

Mersmann HJ (1990) Metabolic and endocrine control of adipose tissue accretion. In Reducing Fat in Meat Animals, pp. 101-144 [JD Wood and AV Fisher, editors]. London: Elsevier Applied Science.

Miles EA \& Calder PC (1998) Modulation of immune function by dietary fatty acids. Proceedings of the Nutrition Society 57, 277299.

Minet V, Van Eenaeme C, Raskin P, Dufrasne I, Clinquart A, Hornick JL, Diez M, Mayombo P, Baldwin P, Bienfait J-M \& Istasse L (1996) Stratègies d'Engraissement du Taurillon Blanc Bleu Belge Culard (Fattening Strategies for Double Muscled Belgian Blue White Bulls). Brussels: Ministerie van Middenstand en Landbouw.

Murphy JJ, Connolly JF \& McNeill GP (1995) Effects on cow performance and milk fat composition of feeding full fat soya beans and rapeseeds to dairy cows at pasture. Livestock Production Science 44, 13-25.

Murphy JJ \& O'Mara F (1993) Nutritional manipulation of milk protein concentration and its impact on the dairy industry. Livestock Production Science 35, 117-134.

Nicolisi RJ (1997) Dietary fat saturation effects on low-densitylipoprotein concentrations and metabolism in various animal models. American Journal of Clinical Nutrition 65, 1617S$1627 \mathrm{~S}$.

Noble RC, Moore JH \& Harfoot CG (1974) Observations on the pattern of biohydrogenation of esterified and unesterified linoleic acid in the rumen. British Journal of Nutrition 31, 99-108.

O'Kelly JC \& Spiers WG (1991) Influence of host diet on the concentrations of fatty acids in rumen bacteria from cattle. Australian Journal of Agricultural Research 42, 243-252.
Palmquist DL \& Moser E (1981) Dietary fat effects on blood insulin, glucose utilization and milk protein content of lactating cows. Journal of Dairy Science 64, 1664-1670.

Precht D \& Molkentin J (1995) Trans fatty acids: implications for health, analytical methods, incidence in edible fats and intake. Die Nahrung 39, 343-374.

Precht D \& Molkentin J (1997) Vergleich der Fettsäuren und der Isomerenverteilung der trans-C18:1-Fettsäuren von Milchfett, Margarine, Back-, Brat- und Diatfetten (Comparison of the fatty acids and the isomer distribution of trans-C18:1 fatty acids in milk fat, margarine, baking, grilling and diet fats). Kieler Milchwirtschaftliche Forschungsberichte 49, 17-34.

Reddy PV, Morrill JL \& Nagaraja TG (1994) Release of free fatty acids from raw or processed soybeans and subsequent effects on fiber digestibilities. Journal of Dairy Science 77, 3410-3416.

Sinclair AJ \& O’Dea K (1990) Fats in human diets through history: is the Western diet out of step. In Reducing Fat in Meat Animals, pp. 1-47 [JD Wood and AV Fisher, editors]. London: Elsevier Applied Science.

Truswell AS (1995) Dietary Fat: Some Aspects of Nutrition and Health and Product Development. ILSI Europe Concise Monograph Series. Brussels: ILSI Press.

Urbach G (1990) Effect of feed on flavor in dairy foods. Journal of Dairy Science 73, 3639-3650

Van Amburgh ME (1997) Effect of ionophores on growth and lactation in cattle. In Proceedings of the Cornell Nutrition Conference for Feed Manufacturers, pp. 93-103. Ithaca, NY: Cornell University Press.

Van Dokkum W (1995) Novel foods. De Waren-Chemicus 25, 98-104.

Van Eenaeme C, Clinquart A, Baldwin P, Mayombo P, Istasse L \& Bienfait J-M (1991) Metabolic and hormonal effects of a fat concentrate in the diet of growing and fattening bulls of different breeds. Mededelingen Faculteit Landbouwwetenschappen Rijksuniversiteit Gent 56, 1601-1610.

Van Nevel C \& Demeyer D (1996a) Lipolysis and biohydrogenation of soyabean oil in the rumen in vitro: inhibition by antimicrobials. Journal of Dairy Science 78, 2797-2806.

Van Nevel CJ \& Demeyer D (1996b) Effect of pH on biohydrogenation of polyunsaturated fatty acids and their Ca-salts by rumen micro-organisms in vitro. Archives of Animal Nutrition 49, 151-157.

Van Nevel CJ \& Demeyer DI (1996c) Influence of pH on lipolysis and biohydrogenation of soyabean oil by rumen contents in vitro. Reproduction Nutrition Développement 36, 53-63.

Van Nevel C, Fievez V \& Demeyer D (1999) Lipolysis and biohydrogenation of PUFAs from fish oil during in vitro incubations with rumen contents. Proceedings of the Nutrition Society (In the Press)

Vatansever L, Kurt E, Enser M, Scollan ND, Richardson RI, Nute GR \& Wood JD (1998) The quality of beef from steers fed supplements of $n-3$ polyunsaturated fatty acids. In Proceedings 44th International Congress of Meat Science and Technology, Barcelona, Spain, pp. 656-657 [A Diestre and JM Monfort, editors]. Barcelona: IRTA.

Vernon RG \& Flint DF (1988) Lipid metabolism in farm animals. Proceedings of the Nutrition Society 47, 287-293.

Webb EC, De Smet S, Van Nevel C, Martens B \& Demeyer DI (1998) Effect of anatomical location on the composition of fatty acids in double-muscled Belgian Blue cows. Meat Science 50, $45-53$.

Weisbjerg MR, Børsting CF \& Hvelplund T (1992) The influence of tallow on rumen metabolism, microbial biomass synthesis and fatty acid composition of bacteria and protozoa. Acta Agricultura Scandinavica 42A, 138-147.

Willett WC, Stampfer MJ, Manson JE, Colditz GA, Speizer FE, Rosner BA, Sampson LA \& Hennekens CH (1993) Intake of 
trans fatty acids and risk of coronary heart disease among women. Lancet 341, 581-585.

Wolff RL (1995) Content and distribution of trans-18: 1 acids in ruminant milk and meat fats. Their importance in European diets and their effect on human milk. Journal of the American Oil Chemists Society 72, 259-272.

Wood JD (1984) Fat deposition and the quality of fat tissue in meat animals. In Fats in Animal Nutrition, pp. 407-435 [RJ Wiseman, editor]. London: Butterworths.

Wood JD (1990) Consequences for meat quality of reducing carcass fatness. In Reducing Fat in Meat Animals, pp. 344-397
[JD Wood and AV Fisher, editors]. London: Elsevier Applied Science.

Wood JD \& Enser M (1997) Factors influencing fatty acids in meat and the role of antioxidants in improving meat quality. British Journal of Nutrition 78, Suppl. 1, S49-S60.

Wu Z, Ohajuruka OA \& Palmquist DL (1991) Ruminal synthesis, biohydrogenation and digestibility of fatty acids by dairy cows. Journal of Dairy Science 74, 3025-3034.

Zock PL \& Katan MB (1997) Trans fatty acids, lipoproteins, and coronary risk. Canadian Journal of Physiology and Pharmacology 75, 211-216. 
